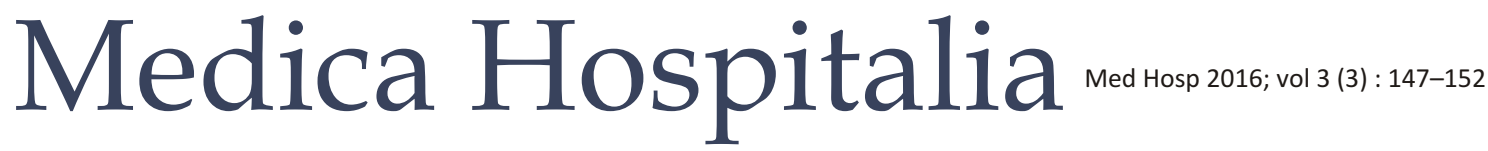

Original Article

\section{Perbedaan Pengaruh Pemberian Diltiazem Dibandingkan Kontrol Terhadap Hitung Jenis Infiltrasi Netrofil pada Luka Incisi Tikus Wistar}

\author{
Septian Adi Permana ${ }^{1}$, Purwoko $^{1}$, Harsono Salimo ${ }^{2}$ \\ ${ }^{1}$ Bagian Anestesiologi dan Terapi Intensif RSUD Dr. Moewardi/FK Universitas Sebelas Maret \\ ${ }^{2}$ Bagian IImu Kesehatan Anak RSUD Dr. Moewardi/FK Universitas Sebelas Maret
}

\begin{abstract}
Abstrak
Latar belakang : Nyeri kronis pasca bedah dapat disebabkan karena proses inflamasi yang terjadi. Proses inflamasi pasca bedah dimulai dengan pelepasan mediator inflamasi oleh sel residen, dimana yang muncul paling awal adalah neutrofil. Diltiazem memiliki efek pencegahan terhadap infiltrasi neutrofil, yang lebih lanjut juga akan mencegah pelepaskan berbagai mediator, termasuk sitokin proinflamasi oleh neutrofil. Penelitian ini bertujuan untuk mengamati apakah pemberian diltiazem efektif dalam mengendalikan reaksi inflamasi yang terjadi pasca incisi, dengan menghitung perbedaan skor histologi hitung jenis infiltrasi neutrofil jaringan.

Metode : Merupakan penelitian eksperimental laboratorik dengan desain randomized controlled trial. 30 ekor tikus wistar dibagi menjadi dua kelompok. K1 merupakan kelompok kontrol terdiri dari 15 ekor tikus yang dilakukan incisi sepanjang $1 \mathrm{~cm}$ dengan pemberian placebo, dan K2 merupakan kelompok perlakuan terdiri dari 15 ekor tikus yang dilakukan incisi sepanjang $1 \mathrm{~cm}$ yang diberikan diltiazem oral. Pemeriksaan neutrofil menggunakan pengecatan hematoksilin eosin yang dilakukan setelah hari pertama pasca incisi.

Hasil : Menunjukkan adanya perbedaan yang bermakna diantara kedua kelompok dengan $p=0,000 ; p<0,05$. Rerata dari kelompok dengan pemberian diltiazem memperlihatkan hasil yang lebih rendah jika dibandingkan dengan kelompok yang tanpa pemberian diltiazem.

Simpulan : Pemberian diltiazem efektif dalam mengendalikan reaksi inflamasi yang terjadi pasca incisi, dengan melihat perbedaan jumlah hitung jenis neutrofil pada luka insisi.
\end{abstract}

Kata kunci : Diltiazem, neutrofil, luka incisi, respon inflamasi

\section{Effect of diltiazem compared to control in neutrophille infiltration count on incised wound of wistar mouse}

\section{Abstract}

Background : Postsurgical chronic pain is the consquence of inflammation. Inflammatory processes after surgical incision are maintained through the release of inflammatory mediators by resident cell, which neutrophil is the first appeared. Diltiazem has properties as anti-inflammatoric agent by preventing neutrophil infiltration, and further preventing release of several mediator, including proinflammatory cytokine by neutrophil. The purpose of this study was to identify effect of diltiazem in reduce inflammatory response after surgical incision, base on differentiation of tissue neutrophil infiltration count in rat with and without oral diltiazem.

Methods : This is a laboratory setting experiment with randomized post test only control group method. Thirty rats were randomly devided in to two groups. K1, fiveteen rats with $1 \mathrm{~cm}$ skin incision and placebo. $\mathrm{K} 2$, fiveteen rats with $1 \mathrm{~cm}$ skin incision and oral ketotifen. After the 1st day, the rats were scrified and the tissue suround the wound were taken for hematoxyllin-eosin stainning. The neutrophil infiltration count were analyzed for histologic scoring.

Results : The histologic score of tissue neutrophil infiltration count of the diltiazem treated group (K2) was significantly lower than control group (K1) ( $p=0.000)$.

Conclusion : administered of oral diltiazem effective reduce inflammatory response to rat with surgical incision.

Keywords : Diltiazem, neutrophil, surgical incision, inflamatory response 


\section{PENDAHULUAN}

Nyeri adalah suatu fenomena komplek meliputi sensoridiskriminatif dan komponen afektif motivasional. Nyeri secara umum dijelaskan sebagai suatu sensasi yang tidak nyaman. Sedangkan menurut definisi dari International Association for the Study of Pain, nyeri didefinisikan sebagai suatu pengalaman sensoris dan emosional yang tidak nyaman yang berhubungan dengan potensi kerusakan jaringan atau sedang mengalami kerusakan jaringan. Nyeri sendiri dibagi berdasarkan perspektif para ilmuwan menjadi nyeri temporal (akut, kronis), mekanistik (nosiseptif, inflamatorik, neuropatik) dan fenomenologik (eudynia, maldynia). ${ }^{1}$

Nyeri inflamatorik ini terjadi karena pada perlukaan jaringan terjadi kondisi inflamasi yang menyebabkan perubahan pada lingkungan nosiseptor dan fungsi dari serabut saraf sensorik. Ketika terjadi inflamasi, berbagai mediator inflamasi dan produk dari kerusakan jaringan dilepaskan dalam beberapa menit sampai beberapa jam, antara lain bradikinin, protease, histamin, serotonin, nitrit oksida, prostanoid, neurotropin, sitokin, ATP, proton, dan mediator lain yang dilepaskan oleh sel sel yang terluka. Kebanyakan produk inflamasi ini dapat mengiritasi / mensensitasi terminal saraf pada area terkena, yang dapat mendorong pada dua konsekuensi yaitu pembentukan sinyal nosiseptif, dan inflamasi neurogenik. Yang terakhir ini dapat menyebabkan pelepasan langsung dari neuropeptida atau pelepasan secara tidak langsung katekolamin pada saraf efferen simpatis. Keduanya dikenal karena efek vasoaktifnya dan juga berbagai efek pada sistem imun. Gabungan dari kedua konsekuensi inilah yang mengakibatkan terjadinya nyeri inflamatorik. $^{2}$

Pada proses inflamasi, penimbunan sel-sel darah putih, terutama neutrofil dan monosit pada lokasi perlukaan merupakan aspek terpenting. Beberapa produk sel darah putih merupakan penggerak reaksi radang, dan pada hal-hal tertentu menimbulkan kerusakan jaringan yang berarti. Proses migrasi sel darah putih ke jaringan yang mengalami perlukaan disebabkan oleh pengaruh-pengaruh kimia yang dapat berdifusi disebut kemotaksis. Hampir semua jenis sel darah putih dipengaruhi oleh faktor-faktor kemotaksis dalam derajat yang berbeda-beda. Neutrofil dan monosit paling reaktif terhadap rangsang kemotaksis. Sel neutrofil adalah sel darah putih pertama yang melakukan migrasi dari pembuluh darah ke tempat cedera. Fungsi neutrofil adalah untuk memfagositosis bakteri dan debris selular. Neutrofil polimorfonuklear (PMN) tertarik ke daerah inflamasi oleh faktor kemotaktik, sel kupfer, komplemen (C3a, C5a), dan sitokin penghasil kemoatraktan (TNF a, il 1, il 6, il 8, il 12, CSF) dimana sitokin ini dalam produksinya diregulasi oleh NFkB. Neutrofil juga melepaskan zat-zat kimia yang yang menarik sel darah putih lain ke tempat peradangan, dengan proses yang disebut kemotaksis. ${ }^{3}$

Calsium channel blockers (CCB) selama ini digunakan sebagi terapi pada penyakit jantung iskemik, gagal jantung, serta aritmia. Studi terbaru menunjukkan bahwa CCB juga sukses digunakan pada proses inflamasi. Pada penelitian Yasuo Yamaguchi, Jian Liang, dkk (2000) menunjukkan bahwa cytokine induce neutrofil chemoattractant (CINC) yang bertugas memanggil neutrofil pada proses inflamasi dihasilkan melalui regulasi NFkB. Dari penelitian ini pun diketahui bahwa aktivasi NFkB disebabkan oleh hubungan antara ion kalsium dan kalmodulin. Dan CCB terbukti mencegah aktivasi NFkB yang kemudian akan menghambat CINC dan pada akhirnya pelepasan neutrofil juga terhambat. ${ }^{3}$

Penelitian yang dilakukan oleh John Haddad (2007) membuktikan bahwa NFkB berperan dalam regulasi nyeri inflamatorik. Peran NFkB ini adalah sebagai faktor transkripsi yang berpengaruh dalam pelepasan mediator-mediator inflamasi yang akan menyebabkan nyeri dan hiperalgesia. Pada inflamasi NFkB berpengaruh dalam pelepasan kemokin, sitokin, peptida antimikrobial, molekul adhesi, INOS, COX $2{ }^{4}$

Pada penelitian Yasuo Yamaguchi, Jian Liang, dkk (2000) menunjukkan bahwa CINC yang bertugas memanggil netrofil pada proses inflamasi dihasilkan melalui regulasi NFkB yang akan menghasilkan sel Kupffer sebagai penghasil CINC. Dari penelitian ini pun diketahui bahwa aktivasi NFkB disebabkan oleh hubungan antara ion kalsium dan kalmodulin. Dan penghambat kanal kalsium terbukti mencegah aktivasi NFkB yang kemudian akan menghambat CINC dan pada akhirnya pelepasan netrofil juga terhambat. ${ }^{3}$

Secara spesifik pada penelitian Iyad Fansa, dkk (2003) diltiazem terbukti menurunkan jumlah netrofil pada proses inflamasi yang terjadi. Disamping itu diltiazem juga terbukti menurunkan kadar CINC yang ada. Dosis diltiazem yang dipakai adalah 1 $\mathrm{mcg} / \mathrm{kg} /$ menit. $^{5}$

\section{METODE}

Penelitian ini termasuk eksperimental laboratorik dengan desain Randomized Controlled Trial yang menggunakan tikus wistar sebagai obyek penelitian dengan tujuan mencari pengaruh pemberian diltiazem terhadap hitung jenis infiltrasi neutrofil pada luka sekitar insisi. Untuk analisis bivariat, di mana pada penelitian terdapat satu variabel bebas yaitu pemberian diltiazem dan satu variabel terikat yaitu hitung jenis infiltrasi netrofil, maka besar sampel minimal dapat menggunakan pedoman "rule of thumb". Dengan "rule of thumb" maka besar sampel yang diperlukan adalah 30, jadi masing-masing kelompok adalah $15 .{ }^{6}$

Kelompok penelitian dibagi menjadi dua yaitu 
kelompok kontrol (K1), dan perlakuan (K2), penjelasannya sebagai berikut:

K1 : Kelompok Kontrol, tikus wistar yang dilakukan insisi sepanjang $1 \mathrm{~cm}$, dengan pemberian placebo.

K2 : Kelompok perlakuan, tikus wistar yang dilakukan insisi sepanjang $1 \mathrm{~cm}$, yang diberikan diltiazem oral dari satu jam sebelum insisi sampai satu hari setelah insisi. Pemberian tiap 6 jam dengan dosis yang telah dikonversi yaitu $2 \mathrm{mg}{ }^{7}$

Skema rancangan penelitian adalah sebagai berikut:

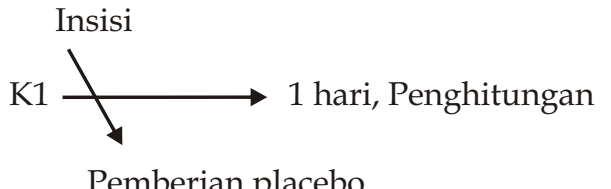

Pemberian placebo

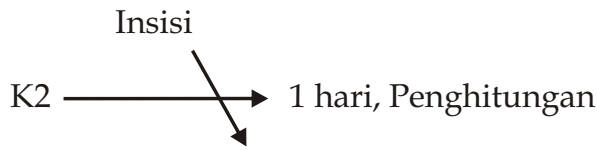

Pemberian diltiazem 2 mg tiap 6 jam

Dari masing-masing kelompok dilakukan fiksasi dengan blok parafin, kemudian dilakukan pemeriksaan histopatologi dengan pewarnaan hematoksilin eosin untuk menentukan skor histologi dari hitung jenis infiltrasi neutrofil jaringan. Dari skor histologi yang sudah diketahui, maka selanjutnya dibandingkan antara skor histologi dari kelompok kontrol dan skor histologi dari kelompok perlakuan.

Setelah data terkumpul, data dianalisis dengan menggunakan program SPSS 16.0. Untuk menguji perbedaan rata-rata hasil hitung jenis infiltrasi netrofil antara dua kelompok dilakukan dengan uji statistik independent t-test, dan dianggap memiliki kemaknaan statistik apabila nilai p yang diperoleh adalah $p \leq 0,05$.

Karena memakai binatang percobaan, maka untuk penelitian ini binatang tikus diperlakukan dengan layak, diberikan kandang yang bersih, cahaya yang cukup, serta makanan dan minuman yang cukup. Perlakuan binatang percobaan yang menimbulkan nyeri dilakukan dengan menggunakan anestesi untuk meminimalkan penderitaan pada hewan coba. Sebelum dilakukan prosedur eksisi-biopsi, tikus dimatikan dengan menggunakan cara dislokasi tulang belakang, dengan dilakukan anestesi umum sebelumnya.

\section{Sampel Penelitian}

Hewan coba adalah tikus wistar yang diperoleh dari Laboratorium Hewan Coba Universitas Sebelas Maret, berjumlah 30 ekor.
1. Kriteria Inklusi :

a. Tikus wistar keturunan murni

b. Berjenis kelamin betina

c. Belum pernah digunakan untuk penelitian

d. Umur $2-2 \frac{1}{2}$ bulan

e. Berat badan 250-300 gram

2. Kriteria Eksklusi

a. Tikus wistar sakit selama masa adaptasi 7 hari (gerakan tidak aktif)

b. Mati selama perlakuan berlangsung

c. Infeksi di sekitar tempat yang akan dilakukan insisi

3. Besar Sampel

Untuk analisis bivariat, di mana pada penelitian terdapat satu variabel bebas yaitu pemberian diltiazem dan satu variabel terikat yaitu skor histologi neutrofil, maka besar sampel minimal dapat menggunakan pedoman "rule of thumb". Dengan "rule of thumb" maka besar sampel yang diperlukan adalah 30, jadi masing-masing kelompok adalah 15 (Murti, 2010).

4. Randomisasi

30 tikus dikelompokkan secara random dengan cara randomisasi sederhana menjadi dua kelompok yaitu: Kelompok K1 : 15 tikus

Kelompok K2 : 15 tikus

\section{HASIL}

Infiltasi neutrofil jaringan dari tiap kelompok dilihat dengan menggunakan pengecatan khusus H-E. Hasilnya dihitung dengan menggunakan mikroskop Olympus BW 51, dengan pembesaran 1000x, pada lima lapang pandang dan dihitung sel yang positif pada lapang pandang tersebut.

Hasil pengamatan rerata skor histologi infiltrasi neutrofil jaringan pada tikus yang dilakukan incisi, menunjukkan adanya perbedaan antara kelompok kontrol (tanpa pemberian diltiazem) dibandingkan dengan kelompok perlakuan (dengan pemberian diltiazem).

Dari grafik box plot berikut terlihat bahwa rerata skor histologi infiltrasi neutrofil jaringan kelompok perlakuan (dengan pemberian diltiazem) lebih rendah dibandingkan dengan kelompok kontrol (tanpa pemberian diltiazem)

\section{Uji Normalitas}

Uji Normalitas ditujukan untuk mengetahui apakah data laboratoris terdistribusi normal atau tidak. Pengujian dilakukan dengan uji Shapiro-Wilk. 


\begin{tabular}{|c|c|c|}
\hline \multicolumn{3}{|c|}{$\begin{array}{l}\text { Data penelitian rerata skor histologi infiltrasi } \\
\text { neutrofil jaringan }\end{array}$} \\
\hline No. & $\begin{array}{l}\text { Tanpa pemberian } \\
\text { diltiazem }\end{array}$ & $\begin{array}{c}\text { Dengan pemberian } \\
\text { diltiazem }\end{array}$ \\
\hline 1 & 15 & 4 \\
\hline 2 & 10 & 3 \\
\hline 3 & 9 & 4 \\
\hline 4 & 11 & 3 \\
\hline 5 & 10 & 3 \\
\hline 6 & 15 & 5 \\
\hline 7 & 25 & 7 \\
\hline 8 & 11 & 4 \\
\hline 9 & 12 & 5 \\
\hline 10 & 12 & 5 \\
\hline 11 & 10 & 5 \\
\hline 12 & 16 & 2 \\
\hline 13 & 16 & 4 \\
\hline 14 & 13 & 3 \\
\hline 15 & 10 & 2 \\
\hline
\end{tabular}

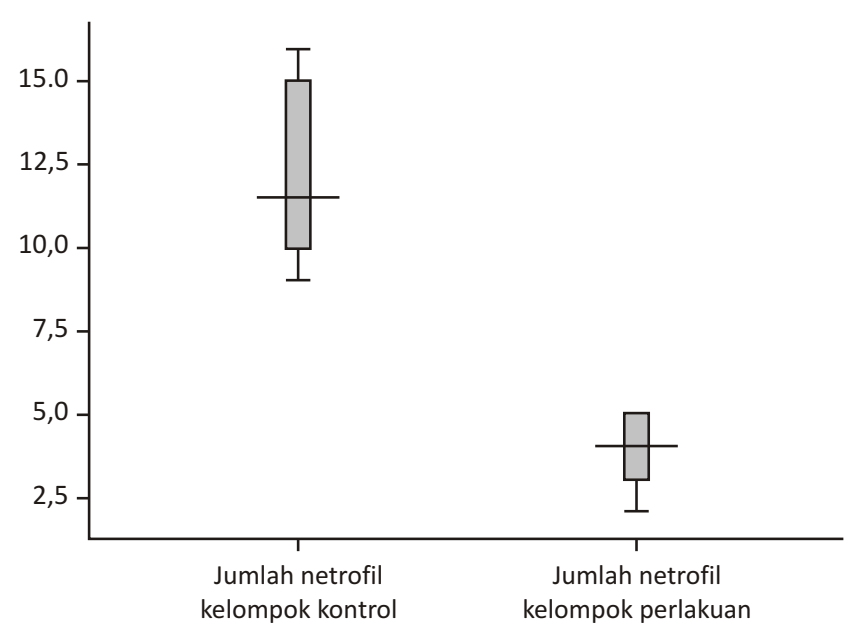

Gambar 1. Grafik box plot rerata skor histologi infiltrasi neutrofil jaringan

Dari tabel 2 menunjukkan kelompok kontrol atau tanpa pemberian diltiazem mempunyai varians data $\operatorname{normal}(p=0,057 ; p>0,05)$.

Dari tabel 3 menunjukkan kelompok perlakuan atau dengan pemberian diltiazem mempunyai varian data normal $(p=0,062 ; p>0,05)$.

\begin{tabular}{|lcc|}
\hline \multicolumn{2}{|l|}{ TABEL 2 } \\
Uji Normalitas data kelompok kontrol \\
\hline Variabel & $\boldsymbol{p}$ & Keterangan \\
\hline $\begin{array}{l}\text { Skor histologi } \\
\text { infiltrasi neutrofil } \\
\text { jaringan }\end{array}$ & 0,057 & Normal \\
\hline
\end{tabular}

TABEL 3

Uji Normalitas data kelompok perlakuan

\begin{tabular}{lcc} 
Variabel & $\boldsymbol{p}$ & Keterangan \\
\hline $\begin{array}{l}\text { Skor histologi } \\
\text { infiltrasi neutrofil } \\
\text { jaringan }\end{array}$ & 0,062 & Normal \\
\hline
\end{tabular}

TABEL 4

Hasil uji beda skor histologi infiltrasi neutrofil jaringan kelompok kontrol dan perlakuan

\begin{tabular}{lccc} 
Variabel & \multicolumn{2}{c}{ Mean Kelompok } & $p^{*}$ \\
& Kontrol & Kontrol & \\
\hline $\begin{array}{l}\text { Skor histologi } \\
\text { infiltrasi neutrofil } \\
\text { jaringan }\end{array}$ & 13,00 & 4,07 & 0,000 \\
\hline
\end{tabular}

*Independent $t$ test

\section{Uji Beda Skor Histologi Infiltrasi Neutrofil Jaringan}

Uji beda skor histologi infiltrasi neutrofil jaringan dilakukan untuk mengetahui apakah ada perbedaan bermakna antara skor histologi infiltrasi neutrofil jaringan pada kelompok kontrol dibandingkan dengan kelompok perlakuan. Uji beda ini dilakukan dengan menggunakan uji statistik independent t-test.

Dari tabel 4 didapatkan adanya perbedaan yang bermakna antara skor histologi infiltrasi neutrofil jaringan pada kelompok kontrol dengan kelompok perlakuan $(p=0,000 ; p<0,05)$. Rerata dari kelompok tikus yang diberikan diltiazem terlihat lebih sedikit dibandingkan dengan kelompok tikus tanpa pemberian diltiazem.

\section{PEMBAHASAN}

Proses inflamasi yang berlebihan dan terjadi secara terus menerus merupakan salah satu sebab dari adanya kejadian nyeri kronis pasca bedah. Proses inflamasi yang terjadi setelah incisi pembedahan diawali dengan adanya 
pelepasan mediator inflamasi di jaringan perifer oleh sel residen dimana salah satunya adalah sel neutrofil. ${ }^{8}$

Diltiazem, dipertimbangkan efektif dalam mengurangi reaksi inflamasi yang berlebihan, melalui perannya dalam mencegah infiltrasi neutrofil ke jaringan. Diltiazem secara spesifik mampu menghambat masuknya kalsium dari sitosol ke intrasel, yang berakibat terhambatnya ikatan imunoglobulin G dengan Fc reseptor. Hal tersebut akan menyebabkan terhambatnya formyl-methionyl-leucyl-phenyl-alanil (fMLP) yang merangsang terjadinya fagositosis sehingga secara tidak langsung menghambat masuknya neutrofil ke jaringan. ${ }^{9}$

Pengambilan biopsi jaringan dilakukan pada hari pertama, dimana neutrofil pada waktu itu didapatkan dalam jumlah yang signifikan. Hasil penelitian menunjukkan adanya perbedaan yang bermakna diantara keduanya dengan $p=0,000 ; p<0,05$ (tabel 4). Rerata dari kelompok dengan pemberian diltiazem memperlihatkan hasil yang lebih rendah (gambar 1) jika dibandingkan dengan kelompok yang tanpa pemberian diltiazem. Untuk uji normalitas menunjukkan kelompok dengan pemberian diltiazem mempunyai varians data normal dengan $p=0,877 ; p>0,05$ (tabel 4.3) dan dari kelompok tanpa pemberian diltiazem juga memperlihatkan varians data yang normal dengan $p=0,209 ; p>0,05$ (tabel 2 ).

Inflamasi yang merupakan respon untuk memperbaiki otot, pertumbuhan dan regenerasi sel bila terjadi secara berlebihan akan justru menyebabkan kerusakan jaringan. Bahkan pada penelitian terbaru menunjukkan secara jelas peran neutrofil dalam menyebabkan kerusakan otot. Tidak ada efek langsung yang menunjukkan peran positif dari neutrofil pada regenerasi maupun perbaikan jaringan. ${ }^{10}$

Neutrofil merupakan salah satu dari agen proinflamasi yang paling awal dan penting dalam induksi dan mengontrol sintesa protein fase akut pada trauma, infeksi, pembedahan, dan luka bakar. Pada inflamasi, neutrofil dan sel mast melepaskan leukotrien dan prostaglandin. Prostaglandin dihasilkan melalui aktivasi jalur siklooksigenase metabolisme asam arakidonat. Prostaglandin yang paling berperan dalam suatu proses inflamasi adalah PGE2, PGD2, dan PGI2 (prostasiklin). PGE2 dan PGI2 menyebabkan peningkatan vasodilatasi dan permeabilitas vaskular, selain itu juga aktivator yang poten bagi osteoclast. PGE2 juga terlibat dalam hyperalgesia dan demam. Aktivasi jalur lipooksigenase metabolisme asam arakidonat menghasilkan leukotrien. ${ }^{11}$

Polimorfonuklear leukosit (PMN) dan sel mast adalah sel utama penghasil leukotrien. Leukotrien B4 (LTB4) potensial untuk kemotaktik PMN dan menyebabkan adhesi PMN ke dinding endotel. Leukotrien lainnya seperti LTC4, LTD4 dan LTE4 adalah faktor kemotaksis untuk eosinofil dan makrofag, meningkatkan permeabilitas vaskular, dan menstimulasi pelepasan lisozim dari PMN dan makrofag. Proses selanjutnya adalah faktor imun seperti interleukin-1a (IL-1 $\alpha)$, interleukin-1 $\beta$ (IL-1 $\beta$ ), tumor necrosis factor- $\alpha$ (TNF- $\alpha)$, tumor necrosis factor- $\beta$ (TNF- $\beta$ ), dan prostaglandin E2 (PGE2). Neutrofil dan makrofag yang mati pada daerah radang, mengeluarkan enzim lisosom dari granul sitoplasma yang menyebabkan kerusakan matriks ekstraselular dan sel. Enzim ini juga mengakibatkan permeabilitas vaskular menjadi meningkat, membebaskan bradikinin, dan mengubah C5 menjadi C5a yang merupakan agen kemotaktik yang poten. Makrofag yang teraktivasi menghasilkan berbagai mediator seperti pro-inflamatori (IL-1, IL-6 dan TNF), sitokin kemotaktik (IL-8), PGE2, PGI2, dan leukotrien B4, C4, D4, dan E4. ${ }^{11}$

Dengan menghambat jumlah infiltrasi neutrofil akan membantu dalam mengendalikan proses inflamasi yang terjadi pasca cedera jaringan, yang selanjutnya diharapkan bahwa pada periode inflamasi yang terjadi dalam tahap-tahap penyembuhan luka, akan berjalan tanpa respon inflamasi yang berlebihan dan berkepanjangan. Akhirnya diharapkan bahwa kejadian nyeri kronis pasca bedah yang salah satunya merupakan konsekuensi dari adanya respon inflamasi yang berlebihan dan berkepanjangan, bisa dicegah dengan penggunaan diltiazem selama perioperatif. 9,10

Pada pelaksanaan penelitian ini, peneliti memiliki keterbatasan pada pemberian obat per oral. Karena metode pengencerannya masih sederhana, maka kesesuaian perhitungan dosis tidak dapat dilakukan dengan sangat presisi. Sehingga perlu dilakukan penelitian lebih lanjut tentang pemberian diltiazem perioperatif terhadap komponen-komponen imunologi lainnya, sehingga bisa lebih memperkuat hasil penelitian ini, dan menambah kemanfaatan dari penelitian ini. Selain itu perlu penelitian lanjutan untuk dapat mengurangi respon inflamasi yang berlebihan dengan harapan kejadian nyeri inflamatorik kronis dapat ditekan.

\section{DAFTAR PUSTAKA}

1. Boswell, M. V., Cole, B. E. 2006. Weiner's Pain Management 7th ed. CRC Press Taylor \& Francis Group. Florida. USA

2. Hunt, S. P., Mantyh, P. W. 2001. The Molecular Dynamics of Pain Control. Nature Neurosci 2: 83-91

3. Liang, J., Yamaguchi, Y., Matsumura, F. 2000. Calcium Channel Blocker Attenuates Kupffer Cell Production of Cytokine Induced Neutrophil Chemoattractant Following Ischemia Reperfusion in Rat Liver. Digestive Disease and Sciences vol 45: 201-209

4. Haddad, J. J. 2007. Molecular Regulation of inflammatory Pain and Hyperalgesia is NFkB the Lynchpin. EXCLI Journal $6: 68-92$

5. Fansa, I., Gol, M. K. 2003. Does diltiazem inhibit the inflammatory response in cardiopulmonary bypass? Med Sci Monit 9(4): PI48-54

6. Murti B. 2010. Desain dan ukuran sampel untuk penelitian 
kualitatif dan kuantitatif di bidang kesehatan. Edisi ke-2 Yogyakarta: Gajah Mada University Press

7. Shaw, S. R., Nihal, M., Ahmad, N. 2007. Dose Translation from Animal to Human Studies Revisited. The FASEB Journal 22 : 659-61

8. Longnecker, D. E., Broen, D. L., Newman, M. F., Zapol, W. M. 2008. Anesthesiology. The McGraw-Hill Companies. Ohio. USA
9. Rosales, C., Brown, E. J. 1992. Calcium Channel Blockers Nifedipine and Diltiazem Inhibit Ca Release from Intracellular Stores in Neutrophils. The Journal of Biological Chemistry

10. Tidball, James G. 2005. Inflamatory Processes in muscle injury and repair. AJP Regu Physiol vol 288 No 2:345-353

11. Kumar, V., Abbas, A. K., Aster, J. C. 2013. Robbins Basic Pathology. Saunders Elsevier. Philadelphia. USA 